Al Qalam: Jurnal Ilmiah Keagamaan dan Kemasyarakatan

Vol. 13, No. 2, 2019

P-ISSN: 1907-4174; E-ISSN: 2621-0681

\title{
FAKTOR-FAKTOR YANG MEMPENGARUHI PERFORMA AUTOMATIC TELLER MACHINE (ATM) PADA BANK SYARIAH MANDIRI CABANG TENGGARONG SEBERANG
}

\author{
Oleh: \\ Dedy Mainata \\ dmainata@gmail.com \\ Fakulas Ekonomi dan Bisnis Islam (FEBI) \\ Institut Agama Islam Negeri (IAIN) Samarinda
}

\begin{abstract}
Automatic Teller Machine (ATM) is a machine that can serve the needs of customers automatically at any time (24 hours) and 7 days a week including holidays. Location ATMs in strategic places. Efforts to improve the bank's fee-based income (FBI) also reflected the addition of machines ATM as one source of FBI of banks. Problems often seen on ATM in Islamic banks is service excellent. ATM location selection is one of the things that can affect the performance of the ATM. ATM placements in strategic locations that do not will have an impact on the quantity of the ATM transactions.

The purpose of this study to find out what are the factors that affect the performance of ATM and the dominant factor affecting the performance of ATM at the Bank Syariah Mandiri branch Tenggarong Seberang. This type of research is descriptive qualitative research sample is purposive sampling.

Factors affecting the performance of ATM at the Bank Syariah Mandiri branch Tenggarong Seberang is a potential FBI, service excellent and marketing strategies.

The dominant factor affecting the performance of ATM at the Bank Syariah Mandiri branch Tenggarong Seberang is service excellent. Tenggarong Seberang local community character is not so concerned related to cleanliness and speed of service. The most important thing is the availability of money at an ATM, however cleanliness, convenience
\end{abstract}

Al Qalam: Jurnal Ilmiah Keagamaan dan Kemasyarakatan Vol. 13, No. 2, Juli-Desember 2019 
Dedy Mainata: Faktor-Faktor yang Mempengaruhi Performa Automatic Teller Machine (Atm) pada Bank Syariah Mandiri Cabang Tenggarong Seberang

and speed of transaction is part of the services should still be maintained BSM Tenggarong Seberang branch.

Keywords: Performance, ATM, Bank Syariah Mandiri.

\section{Pendahuluan}

\section{A. Latar Belakang}

Bank berdasarkan prinsip syariah pada dasarnya berfungsi sama dengan bank konvensional sebagai lembaga intermediasi yaitu mengerahkan dana dari masyarakat dan menyalurkan kembali dana-dana tersebut kepada masyarakat yang membutuhkan dalam bentuk fasilitas pembiayaan dimana kegiatannya tidak berdasarkan prinsip bunga melainkan dengan bagi hasil berdasarkan pembagian keuntungan dan kerugian (profit and loss sharing). Adapuan kegiatan jasa lainnya sama halnya dengan bank konvensional, namun dengan tetap menerapkan prinsip-prinsip dasar syariah dalam kegiatan jasa lainnya ${ }^{1}$.

Setelah disahkannya Undang-Undang No. 21 Tahun 2008 tentang Perbankan Syariah, bank syariah di Indonesia lebih independen dalam melakukan aktifitas kegiatan perbankan berbasis syariah dalam industri perbankan nasional. Berdasarkan Cetak Biru Pengembangan Perbankan Syariah di Indonesia, visi kegiatan pengembangan perbankan syariah adalah terwujudnya sistem perbankan syariah yang kompetitif, efisien, dan memenuhi prinsip kehati-hatian serta mampu mendukung sektor riil secara nyata melalui kegiatan pembiayaan berbasis bagi hasil dan transaksi riil dalam kerangka keadilan, tolong-menolong, dan menuju kebaikan guna mencapai kemashlahatan masyarakat. Penjelasan tersebut menunjukkan bahwa perbankan syariah tidak hanya sekedar lembaga profit namun bertujuan sosial dalam mendukung ekonomi masyarakat².

\footnotetext{
${ }^{1}$ Sutan Remy Sjahdeini, Perbankan Syariah: Produk-Produk dan Aspek-Aspek Hukumnya (Jakarta: Aditya Andrebina Agung, 2015). h. 35-36.

2 Ikatan Bankir Indonesia, Memahami Bisnis Bank Syariah (Jakarta: PT. Gramedia Pustaka Utama, 2018). h. 3-4.
} 
Dedy Mainata: Faktor-Faktor yang Mempengaruhi Performa Automatic Teller Machine (Atm) pada Bank Syariah Mandiri Cabang Tenggarong Seberang

Perkembangan bisnis jasa perbankan syariah yang semakin berkembang, membuat persaingan dalam perbankan syariah semakin ketat terutama bagi usaha yang sasaran segmen pasarnya serupa. Tingkat persaingan dalam perbankan syariah ditandai dengan maraknya produk dan jasa yang ditawarkan dalam bank syariah ${ }^{3}$. Berdasarkan data yang terkumpul dalam statistik perbankan syariah, tahun 2016 total aset bank umum syariah berjumlah 254 Triliun rupiah dan pada tahun 2017 meningkat menjadi 288 Triliun rupiah. Sedangkan jumlah Bank Umum Syariah pada akhir tahun 2017 mencapai 13 bank $^{4}$. Pada tahun 2018 jumlah BUS menjadi 14 bank. Terjadi perkembangan Aset BUS hingga Rp. 316,69 Triliun pada Desember 2018. Jumlah kantor BUS di Indonesia mengalami peningkatan dari 1.825 kantor tahun 2017 menjadi 1.875 kantor pada tahun 2018. Sedangkan jumlah ATM BUS mengalami peningkatan dari 2.585 ATM di tahun 2017 menjadi 2.791 ATM pada 2018.

Perlu adanya strategi baru yang diterapkan dalam industri perbankan dalam upaya menumbuhkan laba, salah satunya dengan memperbesar atau meningkatkan fee based income dari kegiatan jasa perbankan. Strategi ini merupakan suatu tindakan yang diambil oleh industri perbankan dalam upaya mengantisipasi menurunnnya pendapatan dari perolehan bunga penyaluran kredit akibat menurunnya tingkat suku bunga kredit secara umum atau ketika penyaluran kredit mengalami kelesuan ${ }^{5}$. Setiap perusahaan selalu berupaya untuk tetap eksis serta selalu ingin tumbuh dan berkembang. Perusahaan dalam menjalankan aktivitasnya menghadapi tantangan atas kejituan perusahaan itu merumuskan maksud dan tujuan bisnisnya, yaitu untuk menciptakan dan

3 Kasmir, Bank dan Lembaga Keuangan Lainnya (Jakarta: RajaGrafindo Persada, 2003). h.292.

${ }^{4}$ Otoritas Jasa Keuangan Republik Indonesia, Statistik Perbankan Syariah 2017 (Jakarta: Departemen Perizinan dan Informasi Perbankan OJK, 2017). h. 2.

${ }^{5}$ Ketut Tanti Kustina dan IGA Agung Omika Dewi, "Pengaruh Fee Based Income Terhadap Perubahan Laba Perusahaan Perbankan Di Bursa Efek Indonesia," in Prosiding Seminar Nasional Hasil Penelitian (Prosiding Seminar Nasional Hasil Penelitian, Denpasar, 2016). h. 151. 
Dedy Mainata: Faktor-Faktor yang Mempengaruhi Performa Automatic Teller Machine (Atm) pada Bank Syariah Mandiri Cabang Tenggarong Seberang

memelihara pelanggannya ${ }^{6}$. Demikian halnya yang dilakukan bank syariah, strategi peningkatan laba tidak hanya melakukan aktifitas funding dan lending, namun layanan jasa saat ini mulai ditingkatkan guna mendapatkan fee based income sebagai upaya untuk menambah laba bank. Salah satu jasa layanan bank syariah yaitu adanya penyediaan Automatic Teller Machine (ATM).

Fee based income merupakan pendapatan, provisi, fee, atau komisi yang diperoleh bank bukan dari pendapatan bunga, termasuk juga pendapatan yang diperoleh dari pemasaran produk maupun transaksi jasa perbankan. Bagi nasabah, bank yang mempunyai banyak produk bisa menjadi nilai tambah karena memberikan banyak kemudahan layanan jasa perbankan ${ }^{7}$. Dalam hal ini komisi dan provisi kredit dianggap sebagai hasil dari penanaman aktiva produktif sehingga tidak termasuk dalam fee based income ${ }^{8}$.

Tingkat layanan ATM yang baik juga akan mempengaruhi penggunaan ATM dan selanjutnya akan berpengaruh terhadap fee based income bank yang berasal dari ATM. Pemilihan lokasi ATM merupakan salah satu hal yang bisa mempengaruhi performa ATM. Penempatan ATM di lokasi yang tidak strategis tentu akan berdampak pada kuantitas transaksi ATM tersebut. Penempatan ATM pada lokasi-lokasi yang tidak memiliki potensi bisnis misalnya jauh dari pusat pertokoan, jauh dari pasar, jauh dari pusat keramaian akan berdampak pada transaksi pada ATM tersebut. Traksaksi ATM yang sedikit akan berdampak pada fee based income yang kecil. Keputusan saluran pemasaran, dalam hal ini keputusan dalam memilih lokasi ATM merupakan salah satu keputusan yang paling kompleks dan menantang yang dihadapi perusahaan.

${ }^{6}$ Sofjan Assauri, Strategic Marketing Sustainable Lifetime Customer Value (Jakarta: RajaGrafindo Persada, 2013). h. ix.

${ }^{7}$ Kustina dan Dewi, "Pengaruh Fee Based Income Terhadap Perubahan Laba Perusahaan Perbankan Di Bursa Efek Indonesia.” ......., h. 151.

${ }^{8}$ Rusdiyanto dan Ahmad Umar, "Peran Fee Based Income Bagi Pendapatan BRI Syariah Cabang Surabaya," GEMA Ekonomi, Jurnal Fakultas Ekonomi, 04 (Juli 2015). h. 23. 
Dedy Mainata: Faktor-Faktor yang Mempengaruhi Performa Automatic Teller Machine (Atm) pada Bank Syariah Mandiri Cabang Tenggarong Seberang

Saluran yang dipilih secara signifikan akan memengaruhi dan dipengaruhi oleh elemen-elemen lainnya dalam bauran pemasaran ${ }^{9}$.

Bank Syariah Mandiri (BSM) saat ini merupakan bank umum syariah dengan pangsa pasar terbesar di industri bank syariah. Total asset BSM per Desember 2018 sebesar Rp. 98,34 Triliun dengan pembiayaan Rp. 67,75 Triliun dan dana pihak ketiga Rp. 87,47 Triliun, dengan 747 jaringan kantor, 1.040 jaringan ATM BSM. BSM (atau disebut juga Mandiri Syariah) menempati posisi 15 besar bank nasional dari sisi aset dengan pertumbuhan aset yang mencapai 11,86\%. Market share aset per Desember 2018 sebesar 20,60\% sedangkan market share pembiayaan per Desember 2018 sebesar 21,08\% dan market share dana pihak ketiga per Desember 2018 sebesar 23,52\% serta market share fee based income per Desember 2018 sebesar 8,12\%. BSM senantiasa menjaga kecukupan modal Bank untuk dapat memenuhi risiko kredit, risiko pasar dan risiko operasional yang tercermin dari Rasio Kecukupan Modal (Capital Adequacy Ratio-CAR). Pada tahun 2018, Rasio Kecukupan Modal Bank BSM mencapai 16,26\%, mengalami peningkatan 0,36\% dibandingkan dengan Rasio Kecukupan Modal Bank tahun 2017 sebesar 15,89\%. Hal ini berarti bahwa BSM telah mengelola dengan baik modal Bank dan memiliki kecukupan modal untuk melindungi dari risiko solvabilitas. Saat ini BSM memiliki ekuitas sebesar Rp. 8,04 Triliun masuk kategori Bank (Bank Umum berdasarkan Kegiatan Usaha) BUKU III, ini berarti BSM merupakan satusatunya Bank Syariah yang masuk dalam kategori BUKU III ${ }^{10}$.

Pada 08 Juni 2017, Bank Syariah Mandiri mendapatkan penghargaan berupa Banking Service Excellence Award kategori Best ATM. Penghargaan Best ATM yang diraih Bank Syariah Mandiri, berkaitan dengan layanan dan fasilitas terbaik yang disediakan bank. Penghargaan Best ATM yang diraih

9 Thamrin., Abdullah dan Francis. Tantri, Manajemen Pemasaran (Jakarta: RajaGrafindo Persada, 2016). h. 239.

${ }^{10}$ Bank Syariah Mandiri, "Laporan Tahunan Bank Syariah Mandiri 2018" (Jakarta: Bank Syariah Mandiri, 2018). h. 8-11. 
Dedy Mainata: Faktor-Faktor yang Mempengaruhi Performa Automatic Teller Machine (Atm) pada Bank Syariah Mandiri Cabang Tenggarong Seberang

Bank Syariah Mandiri, tidak lepas dari kinerja jaringan ATM dibeberapa wilayah operasional bank, salah satunya adalah wilayah Kalimantan Timur ${ }^{11}$.

Bank Syariah Mandiri cabang Tenggarong Seberang merupakan salah satu cabang BSM yang memiliki prestasi luar biasa pada kinerja ATM nya. BSM cabang Tenggarong Seberang meraih penghargaan fee based income ATM terbaik se BSM nasional selama 4 tahun berturut-turut sejak tahun 2014. ATM BSM cabang Tenggarong Seberang berhasil mencapai nilai fee based income tertinggi se BSM setiap bulannya selama 4 tahun berturut-turut. Bank Syariah Mandiri cabang Tenggarong Seberang berada di Tenggarong Seberang yang diresmikan pada tanggal 15 Oktober 2012 dan mulai beroperasional pada tanggal 18 Oktober 2012. Bank Syariah Mandiri Cabang Tenggarong Seberang berada di Jalan Mulawarman RT 11 Desa Bangun Rejo Kecamatan Tenggarong Seberang Kabupaten Kutai Kartanegara. Ditinjau dari lokasinya, lokasi ATM BSM cabang Tenggarong Seberang cukup jauh dari pusat kota Tenggarong (ibukota Kabupaten Kutai Kartanegara) serta dari Samarinda (ibukota Provinsi Kalimantan Timur). Ditinjau dari pusat keramaian, ATM BSM cabang Tenggarong Seberang juga jauh dari keramaian, tidak ada Mall di sekitar wilayah tersebut, juga tidak ada pasar induk ataupun pasar yang besar di sekitar daerah tersebut. Namun demikian ATM BSM cabang Tenggarong Seberang bisa meraih prestasi ATM terbaik tingkat Nasional. Ini merupakan fenomena yang menarik untuk diteliti.

Berdasarkan pemaparan dan data diatas menarik bagi penulis untuk melakukan penelitian lebih lanjut terkait performa ATM Bank Syariah Mandiri cabang Tenggarong Seberang. Dengan ini penulis mengajukan penelitian dengan judul "Faktor-Faktor yang Mempengaruhi Performa Automatic Teller Machine (ATM) pada Bank Syariah Mandiri cabang Tenggarong Seberang”, yang akan membahas performa ATM BSM cabang Tenggarong Seberang

11 Bank Syariah Mandiri, "Laporan Tahunan Bank Syariah Mandiri 2017" (Jakarta: Bank Syariah Mandiri, 2017). 4-10. 
Dedy Mainata: Faktor-Faktor yang Mempengaruhi Performa Automatic Teller Machine (Atm) pada Bank Syariah Mandiri Cabang Tenggarong Seberang

selama periode 2016-2018, faktor- faktor yang mempengaruhi performa ATM, dan faktor dominan yang mempengaruhinya.

\section{Landasan Teori}

\section{A. Automatic Teller Machine (ATM)}

\section{Pengertian ATM}

Automatic Teller Machine (ATM) atau dalam bahasa Indonesia disebut Anjungan Tunai Mandiri adalah saluran E-Banking paling populer yang kita kenal. Fitur tradisional ATM adalah untuk mengetahui informasi saldo dan melakukan penarikan uang tunai. Bila kita mengenal ATM sebagai mesin untuk mengambil uang, belakangan muncul pula ATM yang dapat menerima setoran uang yang dikenal sebagai CDM (Cash Deposit Machine $)^{12}$.

\section{Komponen ATM}

Komponen yang terdapat di dalam mesin ATM, sehingga mampu melayani berbagai macam transaksi. Sebenarnya komponen ATM terdiri dari kotak ATM, tombol angka (Numeric Keypad), layar monitor dan kamer (optional) sebagai komponen yang biasa nampak dari luar. Sementara didalamnya bisa terdiri dari satu unit computer CPU, keyboard, modem, kotak uang, printer kecil, dan card reader.

\section{Jenis-Jenis ATM}

Selain ATM yang digunakan untuk melakukan penarikan uang, sebenarnya juga terdapat beberapa jenis ATM lainnya, diantaranya ${ }^{13}$ :
a. ATM Setoran Tunai/Cash Deposit Machine
b. ATM Non Tunai
c. Mengenal EDC (Electronic Data Capture)

\footnotetext{
${ }^{12}$ Vyctoria, Bongkar Rahasia E-Banking Security dengan Teknik Hacking dan Carding (Yogyakarta: Penerbit Andi, 2013). h. 4.

${ }^{13}$ Vyctoria,. ........h. 20-22.
} 
Dedy Mainata: Faktor-Faktor yang Mempengaruhi Performa Automatic Teller Machine (Atm) pada Bank Syariah Mandiri Cabang Tenggarong Seberang

\section{Kartu ATM dan Kartu Kredit}

Kartu ATM atau Kartu Kredit kita gunakan untuk melakukan transaksi. Dengan kartu inilah sebuah ATM dapat digunakan, istilah umumnya adalah "tinggal gesek”. Kartu ATM atau kartu kredit inilah yang digesek pada mesin ATM atau sebuah EDC. Metode sistem keamanan penyimpanan data dalam magnetik strip diciptakan oleh IBM pada tahun $1960^{14}$.

\section{B. Konsep Bank Syariah}

Dari berbagai definisi bank maka dapat dikatakan bahwa bank adalah suatu lembaga keu angan yang aktivitasnya menghimpun dana dari masyarakat atau pihak yang memiliki dana kemudian menyalurkannya dalam bentuk pemberian kredit atau pinjaman kepada pihak yang membutuhkan dana yang dinilai layak serta memberikan layanan jasa bank lainnya ${ }^{15}$. Dalam undangundang No. 21 tahun 2008 tentang Perbankan Syariah, disebutkan beberapa pengertian terkait perbankan syariah, yaitu: perbankan syariah adalah segala sesuatu yang menyangkut tentang Bank Syariah dan Unit Usaha Syariah, mencakup kelembagaan, kegiatan usaha, serta cara dan proses dalam melaksanakan kegiatan usahanya.

Dari sisi kelembagaan, bank syariah di Indonesia dapat dibagi ke dalam tiga kelompok, yaitu Bank Umum Syariah (BUS), Unit Usaha Syariah (UUS), dan Bank Pembiayaan Rakyat Syariah (BPRS). Bank Umum Syariah (BUS) adalah bank yang melaksanakan kegiatan usaha berdasarkan prinsip syariah yang dalam kegiatannya memberikan jasa dalam lalu lintas pembayaran. BUS merupakan badan usaha yang setara dengan bank umum konvensional dengan bentuk hukum Perseroan Terbatas, Perusahaan Daerah, atau Koperasi. Seperti

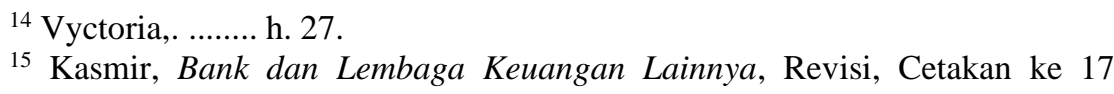
(Jakarta: RajaGrafindo Persada, 2016). h. 24. 
Dedy Mainata: Faktor-Faktor yang Mempengaruhi Performa Automatic Teller Machine (Atm) pada Bank Syariah Mandiri Cabang Tenggarong Seberang

halnya bank umum konvensional, BUS dapat berusaha sebagai bank devisa atau bank non-devisa ${ }^{16}$.

\section{Indikator Performa ATM}

\section{Fee Based Income pada Bank Syariah}

Pentingnya Fee Based Income bagi bank syariah tercermin pada pasal tiga dan empat, peraturan Bank Indonesia tentang sistem penilaian tingkat kesehatan Bank Umum berdasarkan Prinsip Syariah, dimana diversifikasi pendapatan termasuk kemampuan bank untuk mendapatkan fee based income merupakan faktor yang ikut dinilai dalam penilaian tingkat kesehatan bank umum syariah ${ }^{17}$. Faktor lain yang membuat fee based income semakin penting adalah saat ini dan masa yang akan datang persaingan antar bank semakin ketat baik sesama bank syariah maupun antara bank syariah dengan bank konvensional, dengan adanya persaingan yang yang ketat tersebut margin antara cost of fund dengan income from financing (lending) akan semakin menipis, maka other operational income yaitu fee based income akan semakin berperan ${ }^{18}$.

\section{Service Excellent}

Service excellent pada hakikatnya berarti pelayanan yang maksimal atau pelayanan yang terbaik, dan merupakan faktor kunci dalam keberhasilan perusahaan. Dalam hal ini pelayanan prima harus dilakukan secara kontinue dalam keadaan apapun. Layanan ATM Bank tentunya

${ }^{16}$ Grup Riset Kebanksentralan Bank Indonesia, Perjalanan Perbankan Syariah di Indonesia: Kelembagaan dan Kebijakan, serta Tantangan ke Depan (Jakarta: Grup Riset Kebanksentralan Bank Indonesia, 2016). h. 267.

17 Peraturan Bank Indonesia No. Nomor:9/1/PBI/2007, "Tentang Sistem Penilaian Tingkat Kesehatan Bank Umum Berdasarkan Prinsip Syariah" (Jakarta: Bank Indonesia, 2007). h. 5.

${ }^{18}$ Ahmad Umar dan Rusdiyanto, "Peran Fee Based Income Bagi Pendapatan BRI Syariah Cabang Surabaya," GEMA Ekonomi Jurnal Fakultas Ekonomi, 4 (Juli 2015). h. 24.

Al Qalam: Jurnal Ilmiah Keagamaan dan Kemasyarakatan Vol. 13, No. 2, Juli-Desember 2019 
Dedy Mainata: Faktor-Faktor yang Mempengaruhi Performa Automatic Teller Machine (Atm) pada Bank Syariah Mandiri Cabang Tenggarong Seberang

membutuhkan layanan prima yang berkelanjutkan, hal ini berdampak pada performa bank baik dari sisi keuangan ataupun dari sisi manajemen bank ${ }^{19}$.

Manfaat utama dari fokus pelanggan yang kuat dan tingkat kepuasan pelanggan adalah tercapainya tingkat loyalitas pelanggan yang tinggi. Dengan loyalitas pelanggan, prioritas yang diutamakan adalah menjaga hubungan baik dan berkelanjutan dengan para pelanggan. Suatu bisnis perusahaan dengan fokus pelanggan yang kuat akan menjadikan kedudukan terbaik bagi perusahaan untuk pengembangan dan pengimplementasian strategi dalam menyerahkan dan menyampaikan tingkat kepuasan yang tinggi dan loyalitas pelanggan ${ }^{20}$.

\section{Strategi Pasar ATM Bank Syariah}

a. Segmentasi, Targeting, dan positioning

Memahami kebutuhan dan keinginan pasar merupakan aspek krusial yang mendukung kesuksesan strategi pemasaran sebuah perusahaan. Konseskuensinya perusahaan wajib merencanakan segmentasi, targeting, dan positioning secara cermat. Tak kalah pentingnya adalah pemilihan strategi pasar meliputi strategi cakupan pasar, geografis pasar, market entry, komitmen pasar dan market dilution strategy $y^{21}$.

Setelah melakukan segmentasi pasar, langkah berikutnya yaitu melakukan market targeting yaitu proses mengevaluasi daya tarik masing-masing segmen pasar dan memilih salah satu atau beberapa segmen untuk bisa dilayani. Dalam melakukan market targeting, tiga faktor yang perlu diperhatikan yaitu ukuran dan pertumbuhan segmen, daya tarik struktur segmen dan tujuan serta sumber daya perusahaan.

19 Freddy Rangkuti, Customer Care Excellence Meningkatkan Kinerja Perusahaan melalui Pelayanan Prima Plus Analisis Kasas Jasa Raharja (Jakarta: PT. Gramedia Pustaka Utama, 2016). h. 289.

${ }^{20}$ Sofjan Assauri, Strategic Marketing Sustainable Lifetime Customer Value (Jakarta: Raja Grafindo Persada, 2013). h. 5-7. 2015). h. 133.

${ }^{21}$ Fandy Tjiptono, Strategi Pemasaran, 4 ed. (Yogyakarta: Penerbit Andi, 
Dedy Mainata: Faktor-Faktor yang Mempengaruhi Performa Automatic Teller Machine (Atm) pada Bank Syariah Mandiri Cabang Tenggarong Seberang

Selanjutkan setelah penentuan pasar perlu adanya positioning. Hal ini berkenaan dengan upaya identifikasi, pengembangan, dan komunikasi keunggulan yang bersifat khas dan unik sedemikian rupa sehingga produk dan jasa perusahaan dipersepsikan lebih superior dan khusus dibandingkan dengan produk dan jasa lainnya yang ada di pasar. Fokus utama positioning adalah pada persepsi pelanggan dan bukan sekedar produk fisik yang dihasilkan ${ }^{22}$.

b. Analisis Pelanggan/Nasabah

Analisis pelanggan atau nasabah merupakan proses eksternal untuk mengkaji nilai yang ditawarkan, yang dapat dilihat atau dicari oleh perorangan atau kelompok di dalam suatu pasar yang diidentifikasikan oleh analis pasar. Proses pengambilan keputusan bisnis ke konsumen, didasarkan pada Model Lima Tahapan dari Engel, Blackwelland and Miniard (1986). Kelima komponen model ini $\operatorname{adalah}^{23}$ :

1. Masalah.

2. Mencari Informasi.

3. Pengevaluasian.

4. Keputusan pembelian.

5. Pasca-Pembelian.

c. Faktor yang memengaruhi Perilaku Pembelian

Berikut faktor-faktor yang memengaruhi perilaku pembelian konsumen atau nasabah ${ }^{24}$ :

1. Faktor budaya.

2. Faktor Sosial.

3. Faktor Pribadi.

${ }^{22}$ Tjiptono. ........., h. 161.

${ }^{23}$ Dalam Assauri, Strategic Marketing Sustainable Lifetime Customer Value. h. 96-97.

${ }^{24}$ Thamrin, Abdullah dan Francis Tantri, Manajemen Pemasaran (Jakarta: RajaGrafindo Persada, 2016). h. 112-122.

Al Qalam: Jurnal Ilmiah Keagamaan dan Kemasyarakatan Vol. 13, No. 2, Juli-Desember 2019 
Dedy Mainata: Faktor-Faktor yang Mempengaruhi Performa Automatic Teller Machine (Atm) pada Bank Syariah Mandiri Cabang Tenggarong Seberang

4. Faktor Psikologis.

d. Pendekatan dalam pemasaran

Dalam pemasaran dikenal approach (pendekatan) yaitu ${ }^{25}$ :

1. Commodity Approach; Dalam hal ini juga bisa berlaku terhadap pemasaran jasa, khususnya jasa layanan ATM bank syariah.

2. Institutional Approach; Dalam hal ini bisa dipelajari peran mereka dalam pemasaran jasa ATM bank syariah.

3. Functional Approach;

e. Keunggulan Bersaing (Competitive Advantage)

Keunggulan bersaing secara tradisional telah digambarkan sebagai faktor atau kombinasi dari faktor-faktor yang membuat suatu organisasi memiliki kinerja yang lebih baik dibandingkan dengan organisasi lainnya dalam suatu industri atau pasar produk yang sama atau dalam suatu lingkungan persaingan (Feurer dan Chaharbhagi, 1994; Chaharbhagi dan Linch, 1999). Kinerja yang lebih baik oleh suatu organisasi disebabkan oleh adanya perbedaan dalam atribut atau faktor-faktor perusahaan yang memungkinkan perusahaan melayani pelanggan lebih baik daripada yang dilakukan perusahaan lain, sehingga menciptakan nilai pelanggan yang lebih baik pula, dan mencapai kinerja atau performa yang unggul (superior performance) (Ma, 1999). Atribut faktor-faktor tersebut dapat berupa lokasi yang unggul, dominasi ruang di pasar swalayan, akses yang bersifat ekslusif untuk memberi pasokan, merk dagang yang sudah dikenal, keterampilan, keahlian karyawan, dan efisiensi dalam menjalankan perusahaan (Hayden, 1986). Keunggulan bersaing yang telah dimiliki oleh suatu perusahaan dibangun berlandaskan pada beberapa komponen. Menurut Hill dan Jones (1998) keunggulan biaya dan diferensiasi yang berhasil dicapai suatu perusahaan dibangun dengan

25 Abdul Manap, Revolusi Manajemen Pemasaran (Jakarta: Mitra Wacana Media, 2016). h. 25-26. 
Dedy Mainata: Faktor-Faktor yang Mempengaruhi Performa Automatic Teller Machine (Atm) pada Bank Syariah Mandiri Cabang Tenggarong Seberang

berlandaskan pada efisiensi, kualitas, inovasi dan customer responsiveness ${ }^{26}$.

\section{Penelitian Terdahulu}

Penelitian yang dilakukan oleh Rusdiyanto dan Ahmad Umar (2015) tentang Peran Fee Based Income Bagi Pendapatan BRI Syariah di kota Surabaya. Jenis penellitian yang digunakan dalam penelitian ini adalah penelitian kualitatif dengan tingkat eksplanasi deskriptif. Hasil penelitiannya adalah kesadaran tentang pentingnya peran Fee Based Income untuk meningkatkan pendapatan BRI Syariah Cabang Surabaya sudah ada pada pimpinan dan Staff BRI Syariah Cabang Surabaya. Fee based income perannya belum maksimalnya terhadap pendapatan Bank BRI Syariah. Belum maksimalnya peran fee based income antara lain karena status BRI Syariah yang belum devisa sehingga jumlah jenis produk jasa bank yang dapat menghasilkan Fee Based Income masih terbatas. ${ }^{27}$

Gracious Madamba Massie (2014), meneliti tentang pengaruh Fee Based Income dan Intellectual Capital Terhadap Profitabilitas Pada Industri Perbankan Di Bursa Efek Indonesia. Jenis penelitian ini adalah deskriptif verifikatif. Hasil penelitian dapat disimpulkan Fee based income dan intellectual capital berpengaruh secara simultan terhadap profitabilitas pada industri perbankan di Bursa Efek Indonesia. Fee based income tidak berpengaruh secara parsial terhadap profitabilitas pada industri perbankan di Bursa Efek Indonesia. Value added capital employed berpengaruh secara parsial terhadap profitabilitas pada industri perbankan di Bursa Efek Indonesia. Value added human capital berpengaruh secara parsial terhadap profitabilitas pada industri perbankan di Bursa Efek Indonesia. Structural capital value added

26 Amirullah, Manajemen Strategi: Teori-Konsep-Kinerja (Jakarta: Mitra Wacana Media, 2015). h. 94-96.

${ }^{27}$ Rusdiyanto dan Ahmad Umar, "Peran Fee Based Income Bagi Pendapatan BRI Syariah Cabang Surabaya," GEMA Ekonomi, Jurnal Fakultas Ekonomi, 04 (Juli 2015). 
Dedy Mainata: Faktor-Faktor yang Mempengaruhi Performa Automatic Teller Machine (Atm) pada Bank Syariah Mandiri Cabang Tenggarong Seberang

tidak berpengaruh secara parsial terhadap profitabilitas pada industri perbankan di Bursa Efek Indonesia. ${ }^{28}$

Dwastarini Yuliana Candra Dewi dan Hadri Kusuma (2005), meneliti tentang Analisis Proporsi Perolehan Fee Based Income Bank Pembangunan Daerah (BPD) Di Indonesia (Periode 1999-2003). Penelitian ini menggunakan uji statistik non parametrik Mann-Whitney dan uji regresi linier berganda. Hasil penelitian menunjukkan bahwa tidak ada perbedaan perbedaan perolehan fee based income antara BPD yang berbentuk PT dan yang berbentuk PD. Pendapatan provisi, komisi, dan fee, pendapatan transaksi valuta asing; kenaikan surat berharga, dan pendapatan lainnya berpengaruh secara signifikan terhadap besarnya fee based income secara bersama-sama. Sedangkan variabel yang mempengaruhi besarnya fee based income secara individual hanya variabel pendapatan lainnya. ${ }^{29}$

Ketut Tanti Kustina dan IGA Agung Omika Dewi (2016), tentang Pengaruh Fee Based Income Terhadap Perubahan Laba Perusahaan Perbankan Di Bursa Efek Indonesia. Teknik analisis yang digunakan dalam penelitian ini adalah teknik analisis regresi sederhana dengan terlebih dahulu dilakukan pengujian normalitas data. Berdasarkan pembahasan hasil penelitian, maka diperoleh bukti empiris bahwa fee based income berpengaruh signifikan terhadap perubahan laba terutama pada perusahaan perbankan di BEI yang termasuk 10 Bank dengan laba terbesar di Indonesia.. ${ }^{30}$

Imam Yahya dan Retnandi Meita Putri (2016), tentang Pengaruh Perubahan Biaya Transaksi Kartu ATM pada Tabungan Faedah Terhadap Minat Bertransaksi Nasabah Di BRI syariah KC Semarang. Teknik yang digunakan

${ }^{28}$ Massie, "Pengaruh Fee Based Income dan Intellectual Capital Terhadap Profitabilitas Pada Industri Perbankan Di Bursa Efek Indonesia."

${ }^{29}$ Dewi dan Kusuma, "Analisis Proporsi Perolehan Fee Based Income BPD di Indonesia (Periode 1999-2003)."

${ }^{30}$ Ketut Tanti Kustina dan IGA Agung Omika Dewi, "Pengaruh Fee Based Income Terhadap Perubahan Laba Perusahaan Perbankan Di Bursa Efek Indonesia," in Prosiding Seminar Nasional Hasil Penelitian (Prosiding Seminar Nasional Hasil Penelitian, Denpasar, 2016). 
Dedy Mainata: Faktor-Faktor yang Mempengaruhi Performa Automatic Teller Machine (Atm) pada Bank Syariah Mandiri Cabang Tenggarong Seberang

dalam pengambilan sampel dalam penelitian ini adalah purposive sampling. Berdasarkan hasil analisis yang telah dilakukan, perubahan biaya transaksi kartu ATM memiliki pengaruh yang positif dan signifikan terhadap minat bertransaksi nasabah di BRISyariah KC Semarang. ${ }^{31}$

Perbedaan dengan penelitian terdahulu antara lain adalah penelitian ini meneliti tentang faktor-faktor yang mempengaruhi performa ATM dengan metode penelitian deskriptif kualitatif dan penelitian dilakukan di Bank Syariah Mandiri cabang Tenggarong Seberang.

\section{Metode Penelitian}

\section{A. Jenis Penelitian}

Penulisan dan pembahasan penelitian merupakan jenis penelitian kualitatif, dimana peneliti sebagai instrumen kunci, teknik pengumpulan data dilakukan secara gabungan, analisa data bersifat induktif, dan hasilnya lebih menekankan makna dari pada generalisasi. ${ }^{32}$ Penelitian bersifat deskriptif, yaitu menjelaskan objek yang diteliti dengan cara memberikan deskripsi atau gambaran terhadap masalah yang telah didentifikasi dan dilakukan secara intensif dan terinci terhadap suatu perusahaan. ${ }^{33}$. Penelitian ini mendeskripsikan hasil analisa faktor-faktor yang mempengaruhi performa Automatic Teller Machine (ATM) pada bank syariah studi pada Bank Syariah Mandiri cabang Tenggarong Seberang.

\section{B. Populasi dan Sampel Penelitian}

Jumlah bank syariah dengan kategori Bank Umum Syariah (BUS) di Indonesia, menurut Statistik Perbankan Syariah hingga Desember 2018

31 Imam Yahya dan Retnandi Meita Putri, "Pengaruh Perubahan Biaya Transaksi Kartu ATM (Anjungan Tunai Mandiri) Pada Tabungan Faedah Terhadap Minat Bertransaksi Nasabah Di Brisyariah KC Semarang," Jurnal Economica, VII (Mei 2016). $\& 354$.

${ }^{32}$ Sugiyono, Metode Penilitian Manajemen (Bandung: Alfabeta, 2015). h. 347

${ }^{33}$ Sugiyono, Metode Penelitian Kuantitatif Kualitatif dan R\&D, Cetakan ke 17 (Bandung: Alfabeta, 2012). h. 147. 
Dedy Mainata: Faktor-Faktor yang Mempengaruhi Performa Automatic Teller Machine (Atm) pada Bank Syariah Mandiri Cabang Tenggarong Seberang

mencapai 14 bank. Teknik sampling bersifat purposive sampling ${ }^{34}$. Kriteria yang digunakan, yaitu:

a. Bank memiliki pangsa pasar terbesar di industri Bank Syariah;

b. Bank mendapat penghargaan performa terbaik ATM selama tiga tahun berturut-turut;

c. Bank Syariah yang masuk dalam kategori BUKU III;

d. Bank mempublikasi laporan manajemen dan laporan keuangan selama tiga tahun terakhir.

Berdasarkan kriteria diatas, sampel yang sesuai adalah Bank Syariah Mandiri. Hal ini didasarkan karena Bank Syariah Mandiri selama tiga tahun berturut-turut mendapatkan penghargaan berupa Banking Service Excellence Award kategori Best ATM. Total aset Bank Syariah Mandiri (BSM) memiliki mencapai Rp 87,93 triliun hingga akhir tahun 2017, angka tersebut menjadikan posisi BSM sebagai bank syariah yang memiliki total aset terbesar di Indonesia ${ }^{35}$.

\section{Sumber Data}

Data Primer adalah data yang diperoleh secara langsung dari objek penelitian, yaitu dengan melihat langsung dan mengaksesnya ke situs yang resmi serta mengonfirmasi kebenarannya ${ }^{36}$. Data yang digunakan yaitu data primer berupa hasil wawancara terstuktur dengan pihak bank, untuk menganalisa faktor-faktor yang mempengaruhi performa ATM pada Bank Syariah Mandiri cabang Tenggarong Seberang. Data primer berupa Laporan Tahunan Bank Syariah Mandiri selama tiga tahun terakhir yaitu periode 20162018. Data tersebut diambil untuk melihat aktivitas keuangan khususnya pada performa ATM.

${ }^{34}$ Sugiyono. ......, h. 85 .

35 Fuji Pratiwi, "Aset Mandiri Syariah Capai Rp 80,09 Triliun," Republika.co.id, 10 November 2017, 10 November 2017 edisi. diakses pada 17 Mei 2018.

${ }^{36}$ Sugiyono, Metode Penelitian Kombinasi (Bandung: Alfabeta, 2016). h.308. 
Dedy Mainata: Faktor-Faktor yang Mempengaruhi Performa Automatic Teller Machine (Atm) pada Bank Syariah Mandiri Cabang Tenggarong Seberang

\section{Teknik Pengumpulan Data}

Ada beberapa metode pengumpulan data yang dikenal dalam penelitian kualitatif dan yang paling pokok adalah pengamatan atau observasi dan wawancara atau interview ${ }^{37}$. Ada tiga teknik pengumpulan data yang digunakan:

1. Observasi

Observasi adalah aktivitas terhadap suatu proses atau objek dengan maksud merasakan dan kemudian memahami pengetahuan dari sebuah fenomena berdasarkan pengetahuan dan gagasan yang sudah diketahui sebelumnya, untuk mendapatkan informasi-informasi yang dibutuhkan untuk melanjutkan suatu penelitian ${ }^{38}$. Observasi awal penelitian ini dilakukan pada lima tempat, yaitu BSM cabang Balikpapan, BSM cabang Bontang, BSM cabang Sangatta, BSM cabang Hasan Basri dan BSM cabang Tenggarong Seberang.

Berdasarkan hasil observasi awal di beberapa kantor cabang BSM, dapat penulis tarik kesimpulan bahwa pengembangan dan penyediaan fasilitas terbaik ATM berada di wilayang Tenggarong Seberang. Hal ini akan menjadi landasan penulis untuk melakukan penelitian lebih lanjut terkait performa ATM pada Bank Syariah Mandiri.

2. Wawancara

Instrument yang digunakan dalam teknik wawancara adalah pedoman wawancara yang dapat disusun dalam bentuk matriks wawancara. ${ }^{39}$ Metode ini digunakan untuk memperoleh gambaran yang jelas dilapangan terkait faktor-faktor yang mempengaruhi performa ATM pada Bank Syariah Mandiri. Wawancara yang dilakukan dalam penelitian adalah wawancara terstruktur, yaitu peneliti membuat atau menyusun daftar 2011). h.172.

${ }^{37}$ Bagong Suyanto dan Sutinah, Metode Penelitian Sosial (Jakarta: Kencana,

${ }^{38}$ Sugiyono, Metode Penelitian Pendidikan Pendekatan Kuantitatif, Kualitatif, dan R\&D (Bandung: Alfabeta, 2013). h. 310.

39 Suliyanto, Metode Penelitian Bisnis untuk Skripsi, Tesis \& Disertasi (Yogyakarta: ANDI OFFSET, 2018). h.164-165.

Al Qalam: Jurnal Ilmiah Keagamaan dan Kemasyarakatan

Vol. 13, No. 2, Juli-Desember 2019 
Dedy Mainata: Faktor-Faktor yang Mempengaruhi Performa Automatic Teller Machine (Atm) pada Bank Syariah Mandiri Cabang Tenggarong Seberang

pertanyaan yang kemudian dijadikan panduan dalam melakukan wawancara ${ }^{40}$.

\section{Dokumentasi}

Dalam penelitian ini dokumentasi yang digunakan berupa laporan keuangan bank, laporan manajemen bank, laporan statistik perbankan syariah di Indonesia dan penelitian terdahulu yang mendukung.

\section{E. Teknik Analisis Data}

Dalam penelitian ini, analisis data yang digunakan untuk penelitian kualitatif ini yang penulis gunakan bersifat induktif, yaitu suatu analisis berdasarkan data yang diperoleh, selanjutnya dikembangankan menjadi hipotesis. Bila berdasarkan data yang dapat dikumpulkan secara berulang-ulang dengan teknik trianggulasi, ternyata hipotesis diterima, maka hipotesis tersebut berkembang menjadi teori ${ }^{41}$. Dalam penelitian ini penulis melakukan analisis induktif dimana peneliti membahas secara khusus bagaimana performa ATM pada Bank Syariah Mandiri cabang Tenggarong Seberang, kemudian menganalisa serta menyimpulkan faktor-faktor apa saja yang mempengaruhi performa ATM pada Bank Syariah Mandiri cabang Tenggarong Seberang.

\section{F. Teknik Keabsahan Data}

Data atau informasi yang telah dikumpulkan dalam suatu penelitian kualitatif perlu diuji keabsahannya (kebenarannya) melalui teknik Trianggulasi Metode yaitu informasi atau data yang berasal dari hasil wawancara perlu diuji dengan hasil observasi dan seterusnya.

\section{Hasil Penelitian}

\section{A. Profil Umum Objek Penelitian}

\section{Bank Syariah Mandiri}

Sampai dengan Desember 2018 aset perusahaan mencapai Rp.

98,34 triliun dengan pembiayaan Rp. 67,75 triliun dan dana pihak ketiga

40 Haris Herdiansyah, Metodologi Penelitian Kualitatif (Jakarta: Salemba Humanika, 2010). h. 122. h. 402 .

${ }^{41}$ Sugiyono, Metode Penelitian Manajemen, 4 ed. (Bandung: Alfabeta, 2015). 
Dedy Mainata: Faktor-Faktor yang Mempengaruhi Performa Automatic Teller Machine (Atm) pada Bank Syariah Mandiri Cabang Tenggarong Seberang

sebesar Rp. 87,47 triliun. elain itu, Mandiri Syariah menempati posisi sebagai 15 besar bank nasional dari sisi aset dengan pertumbuhan aset yang mencapai 11,86\%. Bank Mandiri Syariah memiliki 765 kantor layanan di seluruh Indonesia, dengan akses lebih dari 219.642 jaringan ATM. Saat ini Mandiri Syariah memiliki ekuitas sebesar Rp. 8,04 triliun dengan total aset Rp. 98,34 triliun. Saat ini Mandiri Syariah masuk ke kategori Bank BUKU III, bahkan saat ini Mandiri Syariah bersiap naik ke BUKU IV. Saat ini, dengan total cabang sekitar 765 cabang di seluruh Indonesia, Mandiri Syariah memiliki 8 ribu lebih karyawan yang akan didorong untuk terus dapat meningkatkan produktivitas bank ${ }^{42}$.

Rasio Kecukupan Modal (Capital Adequacy Ratio-CAR) pada tahun 2018 Rasio Kecukupan Modal Bank mencapai 16,26\%, mengalami peningkatan $0,36 \%$ jika dibandingkan dengan Rasio Kecukupan Modal tahun 2017 sebesar 15,89\%. Hal ini berarti bahwa Mandiri Syariah telah mengelola dengan baik modal Bank dan memiliki kecukupan modal untuk melindungi dari risiko solvabilitas ${ }^{43}$.

\section{Bank Syariah Mandiri Cabang Tenggarong Seberang}

Bank Mandiri Syariah (BSM) Branch Office Tenggarong Seberang memiliki alamat kantor di Jalan Mulawarman RT. 11 Desa Bangun Rejo Kecamatan Tenggarong Seberang Kabupaten Kutai Kartanegara Provinsi Kalimantan Timur. BSM cabang Tenggarong Seberang diresmikan pada tanggal 15 Oktober 2012 dan mulai beroperasional pada tanggal 18 Oktober $2012^{44}$.

Bank Syariah Mandiri Cabang Tenggarong Seberang saat ini memiliki karyawan sebanyak 14 orang yang terdiri dari Satpam 3 orang, Driver 1 orang, Office Boy 1 orang, Customer Service 1 orang, Teller 2 orang, Back Office 1 orang, Operation Service Manager 1 orang, Marketing

${ }^{42}$ Bank Syariah Mandiri. Laporan Tahunan ...., h. 9-10.

${ }^{43}$ Bank Syariah Mandiri. Laporan Tahunan ...., h. 10-11.

44 Musidi, Hasil Wawancara dengan Branch Manager BSM Tenggarong Seberang, Tertulis, 19 Juni 2019, Tenggarong Seberang. 
Dedy Mainata: Faktor-Faktor yang Mempengaruhi Performa Automatic Teller Machine (Atm) pada Bank Syariah Mandiri Cabang Tenggarong Seberang

Mikro 2 orang, Pawning Staf (gadai emas) 1 orang dan Branch Manager 1 orang $^{45}$.

Total aset BSM Tenggarong Seberang tahun 2017 mengalami peningkatan sebesar 18,97\% dari Rp. 25,19 Miliar (tahun 2016) menjadi Rp. 29,97 Miliar, sedangkan tahun 2018 mengalami peningkatan sebesar 29,30\% dari Rp. 29,97 Miliar menjadi Rp. 38,75 Miliar. Sedangkan laba bersih yang diperoleh BSM Tenggarong Seberang tahun 2017 mengalami peningkatan sebesar 103,34\% dari Rp. 775 juta menjadi Rp. 1,57 Miliar. Demikian juga pada tahun 2018 laba bersih mengalami peningkatan sebesar 40,07\% dari Rp. 1,57 Miliar menjadi Rp. 2,21 Miliar, meskipun peningkatan tidak begitu signifikan seperti tahun 2017 lalu. Berdasarkan data tersebut menunjukkan bahwa kinerja keuangan BSM Cabang Tenggarong Seberang mengalami peningkatan dari segi aset dan laba bersih.

Semakin besar rasio ROA suatu bank, maka semakin besar pula tingkat keuntungan yang dicapai bank dan semakin baik kemampuan manajemen bank dalam mengelola aktiva dan sebaliknya ${ }^{46}$. Rasio ROA tahun 2016 sebesar 3,08\%, sesuai kriteria penilaian kesehatan bank diatas masuk dalam peringkat pertama artinya sangat baik atau sangat sehat. Rasio ROA tahun 2017 mengalami peningkatan 2,18\% menjadi 5,26\%, masuk dalam peringkat pertama yaitu sangat sehat. Sedangkan tahun 2018 rasio ROA menjadi 5,70\% atau meningkat sekitar 0,44\% dari tahun sebelumnya. Secara keseluruhan rasio ROA selama tiga tahun berturut-turut dinilai sangat sehat.

Berdasarkan analisa diatas secara keseluruhan kinerja keuangan BSM Cabang Tenggarong Seberang baik dari segi Aset, Laba dan Rasio tahun 2016-2018 mengalami peningkatan yang siginifikan. Hal ini menarik

${ }^{45}$ Musidi. Hasil Wawancara ..... 19 Juni 2019.

${ }^{46}$ Otoritas Jasa Keuangan, "Surat Edaran OJK Nomor 10/SEOJK.03/2014 Tentang Penilaian Tingkat Kesehatan Bank Umum Syariah dan Unit Usaha Syariah" (Kepala Eksekutif Pengawas Perbankan, 11 Juni 2014), Jakarta.h. 78. 
Dedy Mainata: Faktor-Faktor yang Mempengaruhi Performa Automatic Teller Machine (Atm) pada Bank Syariah Mandiri Cabang Tenggarong Seberang

untuk diperhatikan bahwa BSM Tenggarong Seberang memiliki kinerja keuangan yang baik dan menjadi penunjang kinerja keuangan BSM di wilayah Kalimantan Timur.

\section{B. Performa ATM BSM Cabang Tenggarong Seberang}

BSM Cabang Tenggarong Seberang selama tiga tahun berturut-turut sejak 2016-2018, layanan Automatic Teller Machine (ATM) mendapatkan penghargaan sebagai ATM Terbaik tingkat BSM Nasional, meskipun sejak awal berdiri layanan ATM selalu menunjukkan kinerja yang baik ${ }^{47}$. ATM Bank Syariah Mandiri (BSM) Cabang Tenggarong Seberang, pada tahun 2016 dan 2017 berjumlah dua unit mesin ATM yang berada di branch office BSM Tenggarong Seberang. Pada tahun 2018 mesin ATM bertambah menjadi tiga unit yang, dua unit berada di branch office BSM Tenggarong Seberang dan satu unit berada di swalayan Alfamidi public area BSM Tenggarong Seberang. Dua mesin ATM yang berada di branch office masing-masing pecahan Rp. 50.000 dan Rp. 100.000, sedangkan satu unit di public area pecahan Rp. 50.000. ATM BSM cabang Tenggarong Seberang juga merupakan ATM pemenang Kelas Titanium (pemenang FBI/ATM/Bulan tertinggi dan meningkat dibanding bulan sebelumnya) se BSM Nasional tahun 2018. Kelas Titanium merupakan kelas tertinggi pencapaian fee based income (FBI) per ATM per bulan yang diklasifikasikan oleh BSM. Dua dari Tiga ATM yang dimiliki BSM cabang Tenggarong Seberang selalu memenangkan kontes pada kelas yang bergengsi (Titanium) ini dengan pendapatan FBI perbulan masing ATM bisa mencapai Rp. 60 juta perbulan, dengan rata-rata Rp. 45 juta per bulan ${ }^{48}$.

Semua ATM BSM cabang Tenggarong Seberang berjenis ATM Tarik Tunai, dengan fungsi dan fitur di dalamnya sama dengan mesin ATM pada umumnya, yaitu: Informasi saldo, Transfer, Tarik Tunai, Cek Saldo, Ganti PIN, Pembayaran/Pembelian, Cetak Mutasi, Reg E-banking, Layanan Publik, Seberang.

47 Musidi, Hasil Wawancara dengan Branch Manager BSM Tenggarong

${ }^{48}$ Priyo Borni Ardi, Hasil Wawancara dengan Micro Banking Manager Tenggarong Seberang, Tertulis, 29 Juni 2019, Samarinda.

Al Qalam: Jurnal Ilmiah Keagamaan dan Kemasyarakatan Vol. 13, No. 2, Juli-Desember 2019 
Dedy Mainata: Faktor-Faktor yang Mempengaruhi Performa Automatic Teller Machine (Atm) pada Bank Syariah Mandiri Cabang Tenggarong Seberang

Telekomunikasi, ZIS, Asuransi, Institusi/Akademik, Multi Pembayaran, Net/Cab TV, dan lain sebagainya. Adapun, jenis kartu ATM yang bisa digunakan yaitu semua jenis kartu yaitu GPN, Visa, Mastercard, ATM Prima, ATM Bersama dan sebagainya ${ }^{49}$.

Secara keseluruhan total fee based income tahun 2012 mencapai Rp. 1,12 Miliar, sebesar 65,87\% penyumbang terbesar fee based income tahun 2016 berasal dari ATM yaitu Rp. 738 juta. Pada tahun 2017, fee based income ATM menyumbang 65,56\% atau sekitar Rp. 850 juta dari total keseluruhan fee based income. Di tahun 2018 total pendapatan bank dari fee based income sebesar Rp. 1,61 Miliar, sedangkan fee based income ATM menyumbang sekitar 60,25\% atau Rp. 971 juta dari total keseluruhan.

Berdasarkan hasil wawancara menunjukkan bahwa sumber terbesar pendapatan BSM Cabang Tenggarong Seberang berasal dari E-Channel atau Electronic Channel yaitu berupa ATM, Mobile Banking, Internet Banking, dan Notifikasi Via SMS. Pendapatan fee based income ATM BSM cabang Tenggarong Seberang paling besar transaksinya berasal dari Fee Tarik Tunai Via ATM Bersama, yaitu berkisar 60\% dari total fee based income BSM cabang Tenggarong Seberang, selain itu ada juga transaksi Fee Transfer Via ATM Bersama yang transaksinya berkisar 4,93\%. Hal ini mengindikasikan bahwa pelayanan ATM BSM cabang Tenggarong Seberang memiliki kualitas yang baik sehingga banyak pengguna ATM bank lain menggunakan ATM BSM cabang Tenggarong Seberang untuk bertransaksi. Pendapatan lain bersumber dari fee based income dan margin nasabah pembiayaan, untuk fee based income terbesar berasal dari layanan $\mathrm{ATM}^{50}$. Keuntungan ATM diperoleh karena dukungan dari beberapa faktor diantaranya, potensi wilayah yang dekat dengan area industri pertambangan, monitoring ketersedian uang, maintenance mesin, kebersihan, kenyamanan dan keamanan yang terjaga dengan baik. Hal ini yang

49 Ardi. Hasil Wawancara dengan Micro Banking Manager Tenggarong Seberang ..... 29 Juni 2019.

${ }^{50}$ Akhmad Syarif, Hasil Wawancara dengan Customer Service BSM Tenggarong Seberang, 20 Juni 2019, Tenggarong Seberang. 
Dedy Mainata: Faktor-Faktor yang Mempengaruhi Performa Automatic Teller Machine (Atm) pada Bank Syariah Mandiri Cabang Tenggarong Seberang

membuat layanan ATM BSM Cabang Tenggarong Seberang banyak diminati oleh masyarakat sekitar sebagai pilihan untuk bertransaksi ${ }^{51}$.

\section{Faktor-Faktor yang Mempengaruhi Performa ATM BSM}

Informasi yang didapat berdasarkan hasil wawancara dengan branch manager, area service officer, back office, customer service, serta service manager Bank Syariah Mandiri (BSM) Cabang Balikpapan dan Tenggarong Seberang menunjukkan bahwa terdapat beberapa faktor yang mempengaruhi performa ATM BSM Cabang Tenggarong Seberang, secara garis besar terdapat tiga faktor yang mempengaruhinya yaitu: potensi fee based income (FBI), layanan prima dan strategi pemasaran. Adapun penjelasan masing-masing indikator, yaitu sebagai berikut:

\section{Potensi Fee Based Income}

Performa ATM salah satunya bisa dilihat dari Fee Based Income ATM yang terkumpul. Dari semua pendapatan fee based income BSM cabang Tenggarong Seberang di atas, yang dominan adalah berasal dari fee based income ATM, yaitu berkisar $60 \%$ dari total pendapatan fee based income BSM cabang Tenggarong Seberang, selain itu juga ada pendapatan lain yang cukup besar yaitu Pendapatan Adm Tabungan Mudharabah BSM dan Fee Notifikasi via SMS.

Potensi fee based income ATM di wilayah Tenggarong Seberang cukup besar menyumbang pendapatan bank. Hal ini dapat dilihat dari perkembangan pendapatan fee based income ATM BSM cabang Tenggarong Seberang di atas. Dari data-data di atas juga dapat diketahui bahwa potensi perkembangan fee based income ATM BSM cabang Tenggarong Seberang dominan sangat dipengaruhi oleh banyaknya masyarakat pengguna ATM dari bank lain dikarenakan sebagian besar bekerja di perusahaan pertambangan dengan payroll di Bank Mandiri atau Bank Negara Indonesia maupun Bank Central Asia sehingga jika

\footnotetext{
${ }^{51}$ Iwan, Hasil Wawancara dengan Back Office BSM Tenggarong Seberang.
} 
Dedy Mainata: Faktor-Faktor yang Mempengaruhi Performa Automatic Teller Machine (Atm) pada Bank Syariah Mandiri Cabang Tenggarong Seberang

perkembangan industri pertambangan daerah sekitar mengalami perkembangan maka potensi fee based income ATM BSM cabang Tenggarong Seberang juga dapat lebih meningkat lagi.

Dukungan dari kantor pusat dengan target dan reward yang diberikan, mendorong BSM Cabang Tenggarong Seberang terus meningkatkan fee based income dengan selalu menjadi layanan ATM dengan baik. Untuk mendukung peningkatan fee based income ATM kedepannya, BSM Cabang Tenggarong Seberang berencana menambah mesin ATM yang berlokasi di daerah Separi (3 km dari kantor). Berdasarkan hasil wawancara dan survey yang dilakukan, hanya terdapat satu mesin ATM di wilayah tersebut ${ }^{52}$.

Untuk mencapai performa terbaik fee based income dan mencapai tingkat terbaik BSM secara Nasional secara berkelanjutan, ada target yang harus dicapai oleh BSM Cabang Tenggarong Seberang yaitu ATM dapat diakses 24 jam, ketersediaan uang terjaga dengan baik dan mesin ATM harus rutin dilakukan perawatan berkala. Potensi kedepan untuk peningkatan fee based income ATM dengan menambah ATM dan menempatkan ATM di lokasi-lokasi yang potensial ${ }^{53}$.

Adapun tantangan yang dihadapi dalam mempertahankan performa ATM BSM cabang Tenggarong Seberang, yaitu beberapa perbankan sudah menambah mesin ATM di wilayah Tenggarong Seberang sehingga persaingan cukup ketat. Cara mengatasinya adalah meningkatkan ketersediaan uang pada mesin ATM BSM Tenggarong Seberang, mesin ATM harus selalu dalam kondisi prima, menambah mesin ATM BSM dengan penempatan di lokasi strategis, selalu aktif konfirmasi kebutuhan uang/permintaan uang ke Bank lain, menjaga agar tidak pernah offline,

\footnotetext{
${ }^{52}$ Iwan, Hasil Wawancara dengan Back Office BSM Tenggarong Seberang.

53 Syarif, Hasil Wawancara dengan Customer Service BSM Tenggarong Seberang.
}

Al Qalam: Jurnal Ilmiah Keagamaan dan Kemasyarakatan Vol. 13, No. 2, Juli-Desember 2019 
Dedy Mainata: Faktor-Faktor yang Mempengaruhi Performa Automatic Teller Machine (Atm) pada Bank Syariah Mandiri Cabang Tenggarong Seberang

kurang dari 60 menit jika terjadi kerusakan ATM segera berkordinasi dengan vendor maintenance ATM untuk perbaikan $\mathrm{ATM}^{54}$.

\section{Layanan Prima ATM}

Untuk layanan prima ATM BSM Cabang Tenggarong Seberang selalu fokus mengutamakan pelayanan kepada nasabah, karena BSM merupakan perusahaan jasa dengan tujuan memberikan yang terbaik untuk nasabah dan selalu konsisten memberikan pelayanan yang terbaik. BSM sudah mempunyai standar pelayanan yang wajib dijalankan oleh seluruh pegawainya. Selain itu Satuan Pengamanan (Satpam) juga memiliki peran yang cukup penting dalam layanan ATM BSM cabang Tenggarong Seberang yang beroperasional selama 24 jam, sehingga harus selalu dalam pengawasan dan layanan Satpamnya.

Beberapa faktor layanan prima pada ATM yang dijalankan BSM cabang Tenggarong Seberang, diantaranya ${ }^{55}$ :

a. Selalu menjaga ketersediaan uang di ATM BSM Tenggarong Seberang, baik di hari kerja atau di hari libur;

b. Pelayanan prima yang diberikan sangat baik, seperti ruang selalu dingin, bersih, dan mesin ATM berfungsi dengan baik selama 24 jam;

c. Rutin melakukan maintenance terhadap mesin ATM, perawatan mesin dilakukan setiap tiga bulan sekali atau insidental jika terjadi kerusakan;

d. Jarang sekali terjadi offline pada mesin ATM dan jika terjadi gangguan jaringan (offline), maka petugas bank segera menindaklanjutinya;

${ }^{54}$ Heriyadi, Hasil Wawancara dengan Branch Manager Sebelumnya, Tertulis, 28 Juni 2019, Tenggarong.

${ }^{55}$ BSM Cabang Tenggarong Seberang, Kumpulan Hasil Wawancara dengan Branch Manager, Customer Service, Back Office, dan Service Manager, Tertulis dan Rekaman, 19 Juni 2019, Tenggarong Seberang.

Al Qalam: Jurnal Ilmiah Keagamaan dan Kemasyarakatan Vol. 13, No. 2, Juli-Desember 2019 
Dedy Mainata: Faktor-Faktor yang Mempengaruhi Performa Automatic Teller Machine (Atm) pada Bank Syariah Mandiri Cabang Tenggarong Seberang

e. Adanya dukungan penuh (full support) dari kantor pusat (Head Office) Bank Syariah Mandiri terkait layanan ATM;

f. Adanya satpam yang selalu standby dan menjaga keamanan di area ATM serta berperan sebagai konsultan yang memberikan penjelasan kepada nasabah yang akan menggunakan ATM BSM cabang Tenggarong Seberang.

Standar layanan prima ATM yang dilakukan BSM Cabang Tenggarong Seberang, yaitu ATM dapat diakses selama 24 jam. ATM selalu dimonitoring setiap harinya baik oleh pegawai BSM Tenggarong Seberang maupun dari BSM Kantor Pusat melalui system ataupun langsung melihat kondisi fisik ATM. Hal ini untuk menghindari terjadinya out of cash, baik karena kehabisan saldo ataupun karena kerusakan. Monitoring ATM pada hari kerja biasanya dilakukan oleh Branch Manager langsung dan Branch Operation \& Service Manager (BOSM). Sedangkan untuk hari libur, monitoring dilakukan oleh Kantor Pusat dalam hal ini Electronical Banking Group (EBG), walaupun EBG juga memantau pada hari kerja ${ }^{56}$.

Standar layanan lain yang selalu dijaga adalah ketersedian uang dan offline tidak lebih dari 60 menit, jika terjadi kerusakan di mesin maupun jaringan, serta menjaga ruangan agar selalu bersih. Monitoring dilakukan dengan menjaga mesin dan minimal saldo yang ada di ATM. Pengecekan dilakukan setia hari kerja dan untuk pengisian saldo rata-rata dalam seminggu 3-4 kali pengisian oleh Teller dan BOSM. Jadwal untuk monitoring kebersihan mesin ATM dilakukan dalam seminggu sekali oleh General Support Staf (GSS/Back Office) dan untuk vendor biasanya dilakukan jika terjadi gangguan mesin yang tidak bisa ditangani ${ }^{57}$.

Untuk kebersiham mesin ATM dilakukan setiap hari dan dimonitoring setiap waktu. Kebersihan dilakukan oleh Office Boy (OB) Seberang.

56 Ardi, Hsil Wawancara dengan Micro Banking Manager Tenggarong ${ }^{57}$ Ardi.

Al Qalam: Jurnal Ilmiah Keagamaan dan Kemasyarakatan Vol. 13, No. 2, Juli-Desember 2019 
Dedy Mainata: Faktor-Faktor yang Mempengaruhi Performa Automatic Teller Machine (Atm) pada Bank Syariah Mandiri Cabang Tenggarong Seberang

untuk hari kerja, sedangkan untuk hari libur dilakukan oleh security yang bertugas. Kebersihan menjadi pelayanan utama yang harus diperhatikan. Selalu ada pengharum ruangan dan setiap sebulan sekali oleh vendor pengharum ruangan ${ }^{58}$.

Monitoring kenyamanan ruang ATM misalnya memeriksa fungsi AC, memeriksa pintu atau memeriksa ruang ATM dilakukan setiap hari oleh semua pegawai terutama Back Office (BO). Untuk ATM yang berada di public area, seperti di minimarket Alfamidi, monitoring dilakukan oleh Back Office (BO) dengan cara menghubungi karyawan Alfamidi yang bertugas, atau dengan menghubungi penanggungjawab yang bertugas monitoring ATM dan ini dilakukan setiap hari ${ }^{59}$. Untuk pengecekan ketersediaan uang mengecek melalui System BSM dan untuk gangguan di Mesin ATM kami selalu monitoring dengan cara menghubungi PIC di lokasi Alfa Midi (petugas kasir Alfa Midi). Seminggu Sekali atau setiap hari jika dalam pengecekan di system transaksi dana/saldo tidak berkurang.

\section{Strategi Pemasaran ATM}

Segmentasi pasar BSM cabang Tenggarong Seberang adalah karyawan perusahaan pertambangan dan perkebunan sekitar wilayah kantor. Di wilayah sekitar BSM cabang Tenggarong Seberang terdapat beberapa ATM bank lain. Keberadaan ATM Bank lainnya, yaitu untuk ATM yang berada di inbranch, sekitar area kantor BSM cabang Tenggarong Seberang terdapat ATM BRI yang berjarak sekitar 15 meter. Sedangkan yang di public area, terdapat ATM Bank Mandiri, BNI yang berjarak sekitar 100 meter, ATM BRI serta ATM Bank Kaltimtara sekitar 200 meter dari lokasi kantor BSM Cabang Tenggarong Seberang. Namun, berdasarkan pengamatan pihak BSM, ATM tersebut sering offline dan tidak tersedianya uang di ATM. Seberang.

58 Syarif, Hasil Wawancara dengan Customer Service BSM Tenggarong

${ }^{59}$ Iwan, Hasil Wawancara dengan Back Office BSM Tenggarong Seberang. 
Dedy Mainata: Faktor-Faktor yang Mempengaruhi Performa Automatic Teller Machine (Atm) pada Bank Syariah Mandiri Cabang Tenggarong Seberang

Beberapa strategi pemasaran yang dijalankan pada ATM BSM cabang Tenggarong Seberang, diantaranya ${ }^{60}$ :

a. Lokasi yang strategis, banyak perusahaan pertambangan batubara dan perkebunan di sekitar lokasi ATM BSM Tenggarong Seberang dengan payroll pegawai dari perbankan lain,

b. Lokasi dekat dengan pusat perniagaan (pasar) maupun pertokoan sehingga ada transaksi bisnis di wilayah tersebut,

c. ATM mudah diakses, mudah dilihat (eye catching),

d. Kondisi ruangan ATM nyaman,

e. Adanya potensi kerjasama bisnis di wilayah tersebut,

f. Cross selling yang dilakukan dengan meletakkan brosur di ruang ATM. Brosur yang diletakkan berupa produk BSM, seperti produkproduk pembiayaan (Griya, Keuangan Mikro, Cicil Emas, Gadai) dan produk pendanaan seperti tabungan, deposito dan giro. Inovasi yang dilakukan dalam hal ini adalah penambahan beberapa fitur seperti pembelian token listrik, dan pengamanan berlapis dalam hal melakukan transaksi, yaitu dengan meminta no.pin setiap perubahan transaksi ${ }^{61}$

Inovasi ATM yang dilakukan dalam hal ini adalah penambahan beberapa fitur seperti pembelian token listrik, dan pengamanan berlapis dalam melakukan transaksi, yaitu dengan meminta nomor PIN setiap perubahan transaksi.

\section{Faktor Dominan yang Mempengaruhi Performa ATM BSM}

Dari tiga faktor yang telah disebutkan diatas yaitu fee based income (FBI), layanan prima ATM dan strategi pasar, tentunya ada faktor dominan yang mempengaruhi performa ATM BSM Cabang Tenggarong Seberang yaitu

${ }^{60}$ BSM Cabang Tenggarong Seberang, Kumpulan Hasil Wawancara dengan Branch Manager, Customer Service, Back Office, dan Service Manager, Tertulis dan Rekaman, 19 Juni 2019, Tenggarong Seberang.

61 Musidi, Hasil Wawancara dengan Branch Manager BSM Tenggarong Seberang.

Al Qalam: Jurnal Ilmiah Keagamaan dan Kemasyarakatan Vol. 13, No. 2, Juli-Desember 2019 
Dedy Mainata: Faktor-Faktor yang Mempengaruhi Performa Automatic Teller Machine (Atm) pada Bank Syariah Mandiri Cabang Tenggarong Seberang

Layanan Prima. Berdasarkan hasil keseluruhan proses wawancara, ditemukan fakta bahwa karakter masyarakat daerah Tenggarong Seberang tidak begitu mempermasalahkan terkait kebersihan dan kecepatan dalam layanan. Hal terpenting adalah ketersediaan uang di ATM, namun demikian kebersihan, kenyamanan dan kecepatan bertransaksi merupakan bagian dari pelayanan yang tetap harus dijaga BSM Cabang Tenggarong Seberang ${ }^{62}$. Faktor dominan pada ketersediaan dana agar bisa digunakan untuk berbagai macam transaksi, artinya BSM cabang Tenggarong Seberang harus selalu menjaga kondisi ATM dalam keadaan prima.

\section{Kesimpulan}

Berdasarkan hasil pembahasan penelitian pada bab sebelumnya maka penulis simpulkan berdasarkan rumusan masalah, yaitu:

1. Performa Automatic Teller Machine (ATM) pada Bank Syariah Mandiri cabang Tenggarong Seberang memiliki total fee based income (FBI) tahun 2016 mencapai Rp. 1,12 Miliar, sebesar 65,87\% penyumbang terbesar FBI tahun 2016 berasal dari ATM yaitu Rp. 738 juta. Pada tahun 2017, FBI ATM menyumbang 65,56\% atau sekitar Rp. 850 juta dari total keseluruhan FBI BSM cabang Tenggarong Seberang. Di tahun 2018 total pendapatan bank dari FBI sebesar Rp. 1,61 Miliar, sedangkan FBI ATM menyumbang sekitar 60,25\% atau Rp. 971 juta dari total keseluruhan.

2. Faktor-faktor yang mempengaruhi performa Automatic Teller Machine (ATM) pada Bank Syariah Mandiri cabang Tenggarong Seberang adalah potensi fee based income (FBI), layanan prima dan strategi pemasaran.

3. Faktor dominan yang mempengaruhi performa Automatic Teller Machine (ATM) pada Bank Syariah Mandiri cabang Tenggarong Seberang adalah layanan prima. Karakter masyarakat daerah Seberang.

${ }^{62}$ Syarif, Hasil Wawancara dengan Customer Service BSM Tenggarong 
Dedy Mainata: Faktor-Faktor yang Mempengaruhi Performa Automatic Teller Machine (Atm) pada Bank Syariah Mandiri Cabang Tenggarong Seberang

Tenggarong Seberang tidak begitu mempermasalahkan terkait kebersihan dan kecepatan dalam layanan. Hal terpenting adalah ketersediaan uang di ATM, namun demikian kebersihan, kenyamanan dan kecepatan bertransaksi merupakan bagian dari pelayanan yang tetap harus dijaga BSM Cabang Tenggarong Seberang.

\section{Saran Penelitian}

1. Saran bagi Bank Syariah Mandiri cabang Tenggarong Seberang agar bisa terus menjaga performa terbaik ATM nya. Potensi peningkatan Fee Based Income (FBI) melalui ATM masih cukup besar mengingat kepercayaan yang telah dibangun BSM cabang Tenggarong Seberang kepada pengguna ATM nya sudah sangat baik. Beberapa hal yang bisa dilakukan dalam rangka peningkatan FBI melalui ATM antara lain:

a. Menambah ATM yang ditempatkan pada lokasi yang strategis;

b. Merelokasi ATM yang ditempatkan di Alfamidi mengingat FBI yang dihasilkan masih belum maksimal;

c. BSM bisa menambah fungsi pada ATM seperti ATM Tarik Tunai.

d. Dalam rangka peningkatan FBI, BSM bisa mengembangkan EDC (Electronic Data Capture) nya.

2. Saran untuk peneliti selanjutnya mengembangkan penelitian yang ada dengan menambah objek penelitian pada Bank Syariah lainnya, sehingga bisa diketahui faktor-faktor lain yang dapat mempengaruhi performa ATM. 
Dedy Mainata: Faktor-Faktor yang Mempengaruhi Performa Automatic Teller Machine (Atm) pada Bank Syariah Mandiri Cabang Tenggarong Seberang

\section{Daftar Pustaka}

\section{Buku:}

Abdullah, Thamrin MM., M.Pd., dan Francis. Tantri. Manajemen Pemasaran. Jakarta: RajaGrafindo Persada, 2016.

Amirullah, SE., MM. Manajemen Strategi: Teori-Konsep-Kinerja. Jakarta: Mitra Wacana Media, 2015.

Assauri, Sofjan, Strategic Marketing Sustainable Lifetime Customer Value. Jakarta: RajaGrafindo Persada, 2013.

Bank Indonesia, Grup Riset Kebanksentralan. Perjalanan Perbankan Syariah di Indonesia: Kelembagaan dan Kebijakan, serta Tantangan ke Depan. Jakarta: Grup Riset Kebanksentralan Bank Indonesia, 2016.

Hamidi. Metode Penelitian Kualitatif. Cetakan ke 3. Malang: UMM Press, 2005.

Herdiansyah, Haris. Metodologi Penelitian Kualitatif. Jakarta: Salemba Humanika, 2010.

Ikatan Bankir Indonesia. Memahami Bisnis Bank Syariah. Jakarta: PT. Gramedia Pustaka Utama, 2018.

Kasmir. Bank dan Lembaga Keuangan Lainnya. Jakarta: RajaGrafindo Persada, 2003.

—. Manajemen Perbankan. Jakarta: Rajawali Pers, 2011.

Kasmir. Bank dan Lembaga Keuangan Lainnya. Revisi. Cetakan ke 17. Jakarta: RajaGrafindo Persada, 2016.

Manap, H. Abdul. Revolusi Manajemen Pemasaran. Jakarta: Mitra Wacana Media, 2016.

Pratiwi, Fuji. “Aset Mandiri Syariah Capai Rp 80,09 Triliun.” Republika.co.id. 10 November 2017, 10 November 2017 edisi.

Rangkuti, Freddy. Customer Care Excellence Meningkatkan Kinerja Perusahaan melalui Pelayanan Prima Plus Analisis Kasas Jasa Raharja. Jakarta: PT. Gramedia Pustaka Utama, 2016. 
Dedy Mainata: Faktor-Faktor yang Mempengaruhi Performa Automatic Teller Machine (Atm) pada Bank Syariah Mandiri Cabang Tenggarong Seberang

Sjahdeini, Sutan Remy. Perbankan Syariah: Produk-Produk dan Aspek-Aspek Hukumnya. Jakarta: Aditya Andrebina Agung, 2015.

Sugiyono. Metode Penelitian Kombinasi. Bandung: Alfabeta, 2016.

Metode Penelitian Kuantitatif Kualitatif dan R\&D. Cetakan ke 17. Bandung: Alfabeta, 2012.

—. Metode Penelitian Manajemen. 4 ed. Bandung: Alfabeta, 2015.

Metode Penelitian Pendidikan Pendekatan Kuantitatif, Kualitatif, dan R\&D. Bandung: Alfabeta, 2013.

—. Metode Penilitian Manajemen. Bandung: Alfabeta, 2015.

Suliyanto. Metode Penelitian Bisnis untuk Skripsi, Tesis \& Disertasi. Yogyakarta: ANDI OFFSET, 2018.

Suyanto, Bagong, dan Sutinah. Metode Penelitian Sosial. Jakarta: Kencana, 2011.

Tjiptono, Fandy. Strategi Pemasaran. 4 ed. Yogyakarta: Penerbit Andi, 2015.

Vyctoria,. Bongkar Rahasia E-Banking Security dengan Teknik Hacking dan Carding. Yogyakarta: Penerbit Andi, 2013.

\section{Jurnal:}

Dewi, Dwastarini Yuliana Candra, dan Hadri Kusuma. "Analisis Proporsi Perolehan Fee Based Income BPD di Indonesia (Periode 1999-2003)," SINERG, Edisi Khusus on Finance (2005).

Kustina, Ketut Tanti, dan IGA Agung Omika Dewi. "Pengaruh Fee Based Income Terhadap Perubahan Laba Perusahaan Perbankan Di Bursa Efek Indonesia.” In Prosiding Seminar Nasional Hasil Penelitian. Denpasar, 2016.

Massie, Gracious Madamba. "Pengaruh Fee Based Income dan Intellectual Capital Terhadap Profitabilitas Pada Industri Perbankan Di Bursa Efek Indonesia,” E-Jurnal Katalogis, 2 (Juli 2014).

Rusdiyanto, dan Ahmad Umar. "Peran Fee Based Income Bagi Pendapatan BRI Syariah Cabang Surabaya," GEMA Ekonomi, Jurnal Fakultas Ekonomi, 04 (Juli 2015). 
Dedy Mainata: Faktor-Faktor yang Mempengaruhi Performa Automatic Teller Machine (Atm) pada Bank Syariah Mandiri Cabang Tenggarong Seberang

Umar, Ahmad, dan Rusdiyanto. "Peran Fee Based Income Bagi Pendapatan BRI Syariah Cabang Surabaya," GEMA Ekonomi Jurnal Fakultas Ekonomi, 4 (Juli 2015).

Yahya, Imam, dan Retnandi Meita Putri. "Pengaruh Perubahan Biaya Transaksi Kartu ATM (Anjungan Tunai Mandiri) Pada Tabungan Faedah Terhadap Minat Bertransaksi Nasabah Di Brisyariah KC Semarang," Jurnal Economica, VII (Mei 2016).

\section{Peraturan-peraturan:}

Otoritas Jasa Keuangan. "Surat Edaran OJK Nomor 10/SEOJK.03/2014 Tentang Penilaian Tingkat Kesehatan Bank Umum Syariah dan Unit Usaha Syariah.” Kepala Eksekutif Pengawas Perbankan, 11 Juni 2014. Jakarta.

Otoritas Jasa Keuangan Republik Indonesia. Statistik Perbankan Syariah 2017. Jakarta: Departemen Perizinan dan Informasi Perbankan OJK, 2017.

Statistik Perbankan Syariah 2018. Jakarta: Departemen Perizinan dan Informasi Perbankan OJK, 2018.

Peraturan Bank Indonesia No. Nomor:9/1/PBI/2007. "Tentang Sistem Penilaian Tingkat Kesehatan Bank Umum Berdasarkan Prinsip Syariah.” Jakarta: Bank Indonesia, 2007.

\section{Wawancara:}

Area Consumer Financing Manager BSM cabang Balikpapan. Hasil wawancara dengan Area Consumer Financing Manager BSM cabang Balikpapan, Mei 2019.

Service Manager BSM cabang Bontang, dan Branch Manager BSM cabang Sangatta. Hasil wawancara dengan Service Manager BSM cabang Bontang dan Branch Manager BSM cabang Sangatta, 17 Mei 2019.

Service Manager BSM cabang Hasan Basri Samarinda, dan Branch Manager BSM cabang Tenggarong Seberang. Hasil wawancara dengan Service Manager BSM cabang Hasan Basri Samarinda dan Branch Manager BSM cabang Tenggarong Seberang, 23 dan 27 Mei 2019.

Ardi, Priyo Borni. Hsil Wawancara dengan Micro Banking Manager Tenggarong Seberang. Tertulis, 29 Juni 2019. Samarinda. 
Dedy Mainata: Faktor-Faktor yang Mempengaruhi Performa Automatic Teller Machine (Atm) pada Bank Syariah Mandiri Cabang Tenggarong Seberang

BSM Cabang Tenggarong Seberang. Kumpulan Hasil Wawancara dengan Branch Manager, Customer Service, Back Office, dan Service Manager. Tertulis dan Rekaman, 19 Juni 2019. Tenggarong Seberang.

Heriyadi. Hasil Wawancara dengan Branch Manager Sebelumnya. Tertulis, 28 Juni 2019. Tenggarong.

Iwan. Hasil Wawancara dengan Back Office BSM Tenggarong Seberang, 21 Juni 2019. Tenggarong Seberang.

Musidi. Hasil Wawancara dengan Branch Manager BSM Tenggarong Seberang. Tertulis, 19 Juni 2019. Tenggarong Seberang.

Syarif, Akhmad. Hasil Wawancara dengan Customer Service BSM Tenggarong Seberang, 20 Juni 2019. Tenggarong Seberang.

\section{Website:}

Bank Syariah Mandiri. "Laporan Tahunan Bank Syariah Mandiri 2017." Jakarta: Bank Syariah Mandiri, 2017.

_ . "Laporan Tahunan Bank Syariah Mandiri 2018." Jakarta: Bank Syariah Mandiri, 2018.

Republika. "BSM dinobatkan sebagai Bank Syariah Ritel Terkuat di Asia." Republika.co.id. 23 November 2018. 